Nationalising local sustainability: lessons from the British wartime Utility furniture scheme

Philip Pinch* and Suzanne Reimer ${ }^{\dagger}$

* Department of Urban, Environment and Leisure Studies, London South Bank

University, London United Kingdom

$\dagger$ Geography and Environment, University of Southampton, Southampton, United Kingdom

Corresponding author: Dr Suzanne Reimer Geography and Environment, University of Southampton, Highfield, Southampton SO17 1BJ Email: $\underline{\text { S.Reimer@soton.ac.uk }}$

Accepted 17 July 2015

Online as: Geoforum 65 (2015) 86-95 doi:10.1016/j.geoforum.2015.07.014 


\title{
Nationalising local sustainability: lessons from the British wartime Utility furniture scheme
}

\begin{abstract}
Analyses of sustainable design and commodity networks often make a priori assumptions about the capacity of markets to provide solutions to environmental problems; and have a tendency to celebrate local scales of action. This paper offers a contrasting account, in which the national state sought to carefully manage scarce natural resources and to ensure equitable consumption at a time of deep crisis. We utilise the historical example of the British wartime Utility furniture scheme in order to draw out three lessons for sustainable and equitable environmental practice. First, we argue that national states do not simply provide an institutional backdrop to sustainable production but rather can act as important organising agents. Second, the paper emphasises that sustainability is best achieved through interventions across a commodity network, beyond simply modifications to a single node such as design. Finally, we underscore the value of 'pragmatic centralism' in environmental decision-making, calling attention to the collaborative practices that underpinned the scheme. The example of Utility's adaptive responses - borne out of crisis, scarcity and shortage during wartime - offers much that is of intrinsic interest to current concerns about resource consumption and the drivers of sustainability in commodity networks.
\end{abstract}

Keywords: utility furniture, commodity network, state, equity, environmental sustainability, pragmatic centralism

\section{Introduction}

During the Second World War, the British government under its "Utility" scheme sought strict controls over the production, distribution and pricing of a range of consumer products, such as cloth and clothing, furniture and fabrics, bedding, household textiles, glass, pottery, footwear and hosiery (Attfield 1999; Hargreaves and Gowing 1952). Planned and implemented during the early years of the war, the Utility scheme sought to manage acute shortages of raw materials such as timber, metal, cotton and rubber as well as to facilitate the equitable distribution and consumption of finished consumer goods under conditions of extreme scarcity. Whilst wartime and early post- 
war consumer rationing has tended to be the most well-known element of the mid twentieth century British domestic economy, the broader dynamics and implications of the Utility scheme have been less well understood and analysed. In this paper we use the example of the Utility scheme for furniture to engage with current concerns about drivers of environmental sustainability in commodity networks, including the potential for markets to deliver the sustainable production of consumer goods.

The development of the Utility furniture scheme initially was triggered by commodity shortages that emerged from the immediate collapse of imports as well as the diversion of wood and metal from domestic to wartime production (Ford 1951; House 1962). The concomitant restrictions in the supply of furniture as a finished good at a time of dramatic increases in demand led to racketeering and profiteering in the second hand furniture market; and the state sought to prevent the recurrence of similar abuses which had taken place during the First World War. Consequently, an important perspective is the recognition that the Utility furniture scheme was a necessary political intervention into the market and one for socially equitable purposes.

Under the Utility furniture scheme, the national state made a series of profound interventions across the sector. Furniture design, manufacturing, distribution and consumption were all reorganised (Reimer and Pinch 2013). Production was redistributed away from historic concentrations in London and High Wycombe (Hall 1962) to be taken up by 'designated' firms across the whole of Britain. Designation by the Board of Trade involved a careful selection of manufacturers based on potential production capacity and sufficient labour resources. Firms were not necessarily required to possess highly skilled labour, because furniture design expertise had been standardised and centralised: only a defined set of 'Utility' furniture types could be produced. Designated manufacturers were compelled to supply retailers within 38 
defined 'production zones', based upon existing county boundaries, with some amalgamations in, for example, Devon and Cornwall or Norfolk and Suffolk (Board of Trade 1942-44b). Furniture consumption was both rationed as well as spatially controlled. Buying permits were issued by the Assistance Board on behalf of the Board of Trade to 'priority classes' such as newly married households or those who had been bombed; and permits were only valid at retailers within a 15 mile radius of the address to which the furniture was to be delivered.

The fascinating example of Utility helps us to think about how best to deliver sustainability. The 'local' is much celebrated in the sustainability literature. The idea that the small scale and local is intrinsically more sustainable, adaptive, beautiful and participatory — and that the local is where potential is most deeply embedded — has been a leitmotif running from the Arts and Crafts movement to contemporary green designers. The state or 'the centre' — by inference, if not by explicit statement - has been cast as 'Big', corporate, restrictive, un-adaptive, anti-democratic and inflexible. Although researchers have gone in search of innovative local practice, responses often appear piecemeal and fragmentary. As our account of the Utility furniture scheme will demonstrate, if more geographically widespread change in environmental practice is to be delivered one may have to think about how larger scale interventions, including the role of the national state, have the pragmatic capacities to nationalise forms of local sustainability and equity.

In this regard we wish to outline the distinctive power of what we term 'pragmatic centralism.' As Addison's (1975) account of the formation and actions of the British coalition government reveals, the Second World War was a period of unprecedented intervention by the state into market operations. The experiences of the pre-war economic recession, combined with the shared sacrifice and solidarity of the 
war-effort and home front contributed to an ideological shift which “...spoke always of the rational and centralized control of resources, and the priority which must be given to social welfare"(Addison 1975, 183). The war effort vindicated new mechanisms for more equitable allocation of scarce resources based upon state assessments of social need and collective welfare; and also stimulated collaboration between public and private sector agents. Utility was one element of this pragmatic centralism.

Whilst in many respects a product of the unique political and ideological shifts of the time and of the particular circumstances of war, the example of Utility nevertheless demonstrates the existence of alternative developmental pathways toward social and environmental justice. Further, our historical focus also offers an important contribution to broader debates surrounding commodity chains and networks (see Leslie and Reimer 2006; Reimer and Leslie 2008; Hughes and Reimer 2004), particularly in appreciating “...the historically constructed and politically contingent nature of chains." (Bair 2009, 19).

Drawing upon archival research into the Utility furniture scheme, the paper explores the lessons offered by the scheme for present-day understandings of sustainable production, distribution and consumption. ${ }^{2}$ Section 2 below positions the Utility furniture case study as a counter to current optimism about the power of markets to deliver environmental efficiencies and 'upgrading', by reflecting upon a period of deep economic crisis and market failure. Section 3 uses the example of Utility to develop debates about 'green design' into an understanding of how the delivery of sustainability involves interventions that move beyond the imaginations of design as a pre-production activity to embrace the complexity of broader commodity networks, including nodes of design, production, retailing, distribution and consumption. In Section 4, we present Utility as an expedient and adaptive response to a period of 
resource shortage and a crisis in equitable consumption. Whilst led by the national state, the development and management of the Utility furniture scheme involved collaboration and negotiation among a wide range of participants at a time when the equitable redistribution of material resources was widely accepted: an arrangement which we characterise as pragmatic centralism. The concluding section of the paper reinforces the insights that the Utility example generates for nationalising local sustainability.

\section{Market failure and sustainable commodity networks}

Contemporary neo-liberal discourses do much to celebrate the capacity of globalised markets and supply chains to deliver 'environmental upgrading', in which attention to environmental standards is seen to improve firm competitiveness (see, for example, Khattak et al., 2015). Developed from broader conceptualisations of production upgrading within global value chains (Gereffi et al., 2001), more recent literature has foregrounded the ways in which upgrading might involve moves towards environmental sustainability (Goger 2013; de Marchi, di Maria and Micelli 2013; on the furniture industry in particular, see Handfield et al., 1997; Kaplinsky et al. 2009; Høgelvold 2011; de Marchi, di Maria and Ponte 2013). Through (for example) the use of more sustainable wood sources; the reduction of toxic substances such as volatile organic compounds; the incorporation of recycled materials and/or the general reduction in waste streams, the enhancement of environmental sustainability across the value chain typically is seen as a form of innovation which is able to improve firms', industries' or nations' competitiveness or market position.

Within associated literatures on 'ecological modernisation', economic growth, open international trading conditions and market based incentives, combined with the preferences of environmentally discerning consumers, are viewed as pivotal 
mechanisms for improving the environmental practices of industries and resolving environmental problems. Writing on ecological modernisation thus emphasises the efficacy of voluntary forms of private-sector self-regulation rather than formal legislative control by central government. ${ }^{3}$ A somewhat stronger role for the state is offered within related work on Strategic Niche Management (SNM). SNM is concerned with identifying circumstances under which the unsustainable trajectories and pathdependencies of established techno-economic systems might be changed to embrace more environmentally efficient practices (see Kemp, Schot and Hoogma, 1998; Caniëls and Romijn, 2008; Schot and Geels, 2008). The state is seen as potentially important first, in coordinating diverse actor networks that challenge established vested producer interests and articulating the values of community and environmental groups; and secondly in creating new niches or 'protected spaces' which allow experimentation and innovative practice within economic sectors. However, as Lovell's (2007) analysis of UK low energy housing policy demonstrates, SNM in practice risks becoming a politically expedient approach which ultimately is unable to drive more significant sector wide change.

As ONeill and Gibbs $(2013,2)$ have noted, at the core of the sustainable futures imagined by principles of ecological modernisation is a "commitment to capitalist, consumer-led economies" wherein inequitable outcomes often are overlooked. Similarly_ and despite seemingly offering a possibility for spaces of non-market governance - the interventions of Strategic Niche Management also remain marketoriented. It is instructive, therefore, to turn to the case of Utility in order to emphasise the salutary lessons it provides for approaches which celebrate 'light touch' regulation and are underpinned by market optimism. Our account of the wartime Utility scheme draws attention to two ways in which 'the market' is capable of failure. 


\subsection{Uneven capacities for environmental innovation}

The first sense in which markets can fail is that certain industrial sectors may in practice show little capacity or inclination for adaptive environmental responses. Moreover, even if innovative capabilities exist (including innovation to achieve more sustainable outcomes), these may be distributed unevenly across a national space-economy. The structure of the early twentieth century British furniture industry prior to the introduction of the Utility scheme provides a case in point. Modernisation and advancement within the industry were notoriously deficient. As a post-war Board of Trade report comprehensively detailed, the British furniture industry at the start of the Second World War was highly fragmented (with large numbers of very small firms), was reliant on unskilled labour and showed little capacity for innovation:

except in the largest firms, it is true to say that the industry still bears strong signs of its handicraft origins. Although many firms increased in size in the thirties, they still remain essentially family businesses in character and outlook. Factories are generally old-fashioned and expansion has been achieved by adding extensions to original buildings rather than designing new factories and lay-outs to suit the new techniques of production... It is significant that the firms with separate design, research and costing units working under the direction of trained executives are the exception in this industry (Board of Trade 1946b, 9).

The contemporary critique offered in Nikolaus Pevsner's An enquiry into industrial art in England denounced particular parts of the furniture industry for offering "cheap goods" to an unknowing public $(1937,38)$. Although some design innovation (often via mechanisation) emerged during the early twentieth century within larger firms, this was in stark contrast to most of the rest of the industry (Board of Trade 1946b; Reid 1986; Kirkham et al.1987). Small firms of less than 10 employees, with little capital, were in the majority (Board of Trade, 1946b, 8-9). 
The British furniture industry historically had been concentrated in High Wycombe and the East End of London. High Wycombe's importance, particularly as a location of specialist chair manufacturing, derived not only from its often cited proximity to beech wood in the Chilterns and the local availability of skilled craft workers, but also from the strength of a dense local network of outwork and subcontracting arrangements (Reimer and Pinch 2013, 106). During the inter-war period, the London trade shifted northwards into Tottenham, Edmonton and Walthamstow (Hall 1962). Remaining inner London manufacturers came to serve a smaller-scale, higher quality market whilst in the outer boroughs large scale manufacturing premises (supported by new developments in electrification) began to supply the growing mass market in London and the South-East (Scott and Walsh 2004). By $1935,43.3 \%$ of firms and almost half of all employees were located in the Greater London region, which includes High Wycombe. ${ }^{4}$ Strong geographical concentration as well as the bifurcation of the trade into a few large firms and a vast array of small producers made the furniture industry particularly vulnerable to the crisis circumstances. In the early stages of the war, large furniture manufacturing firms rapidly were drawn into military production, whilst smaller concerns struggled with raw material and labour shortages as well as escalating costs. Key representatives of and actors within the furniture industry including the design reformer Gordon Russell were cognisant of such structural weaknesses and hoped to use wartime state-led interventions to transform it, given a general lack of endogenous capacity to make change occur (see Russell 1968; Design 1974).

It is notable that twenty-first century furniture production remains fragmented, weakly organised and labour-intensive (Scott 1996, 2006). Considerable traditionalism persists within what is still predominantly a low technology manufacturing industry 
which continues to be driven by cost and price concerns. Although Ikea might make broad claims about environmental and design innovation (see, for example, a review of corporate documentation in de Marchi, di Maria and Ponte 2013), the overall market share of this global firm remains relatively small in contrast to its cultural prominence. And whilst design innovation-potentially including the development of eco-design capacity—-may be achieved by some small furniture manufacturing firms who emphasise quality and craft-based production (see Leslie and Reimer 2006; Maskell 1998), there is also evidence that smaller (undercapitalised) businesses struggle to pursue environmental or sustainable production agendas. McIlhenney and Hayter's consideration of a potential "sustainability transition" amongst small wood manufacturers in British Columbia, Canada, for example, reports that "awareness and commitment to green entrepreneurship... is modest and variable" $(2013,19)$; and ONeill and Gibbs (2013) identify the sharp financial and policy challenges faced by 'green entrepreneurs' in the UK building trade.

\subsection{Crisis conditions and consumer markets}

There is a second sense in which markets can fail. Even if industries can develop innovative environmental practices, such responses are reliant upon stable market conditions. As Hough $(2011,19)$ has emphasised, twenty-first century appraisals of global commodity chains contain inherent assumptions about "the durability, expansion and institutionality of global markets." Yet as the Utility example reminds us, markets quickly can become unsettled during periods of economic crisis and at such moments the capacity and willingness of the private sector for environmental adaption and innovation often weakens (Geels 2013). The destabilisation of commodity networks at such moments has the potential to undermine environmental innovation. 
War may represent an extreme event, but nevertheless its effects are revealing. The furniture industry offers an important illustration given that it was one of the first to feel the impacts of war, not least because of its heavy reliance upon imported timber and plywood (Hargreaves and Gowing 1952, 512). Wood predominated in furniture making; and across the whole of the British economy during the interwar period, $96 \%$ of requirements were imported (MacGregor 1953, 299). Hardwood timber was sourced from Canada and the USA whilst softwood typically was imported from Finland, Russia and the Baltic states of Estonia, Latvia and Lithuania (Board of Trade 1949). All wood imports were severely curtailed by the onset of war, and quota schemes were quickly introduced to prioritise military over domestic usage. The impact on the furniture trade was devastating, leading to "the extensive use of poor substitute materials [and] encourage[ing] the production of furniture whose shoddiness was often disguised by decoration" (Hargreaves and Gowing 1952, 513). As an early wartime memorandum recorded: 'the 'cut-offs' of timber used for Government Orders appears to be one source of illicit supplies" (Frost 1942, 2).

Attempts to control the timber content of furniture alongside the setting of a maximum selling price "encouraged still further the production of... poor quality articles (Hargreaves and Gowing 1952, 513), whilst price controls to limit the cost of second-hand furniture to its original selling price were decidedly ineffective, and black markets rapidly emerged:

Mass produced furniture, which was in greatest demand, had risen three, four, five or even six times its pre-war prices. One could not speak of a market but only of 'an unorganised welter of selling prices' (Hargreaves and Gowing 1952, 611).

By early 1942 the problems of furniture scarcity, racketeering and overpricing were compounded by sharp demand increases from bombed-out householders, newly-formed 
families and from a general rise in purchasing power via earnings from war work.

Conscious of socially iniquitous outcomes as furniture shortages intensified, the national state at this point was compelled to intervene even more profoundly and moved to control production and distribution as well as the supply of furniture.

\section{The state, the commodity network and sustainability}

In July 1942 Hugh Dalton, President of the Board of Trade, set up the Advisory Committee on Utility Furniture to:

produce specifications for furniture of good, sound construction in simple but agreeable designs for sale at reasonable prices, and ensuring the maximum economy of raw materials and labour (Board of Trade 1942-1944).

The extent of this state-led intervention into production, distribution and consumption of furniture is instructive, particularly in contrast to the current era which fetishises the capacities and response of private industry. At one level, the national state was innovative in commissioning new resource-efficient designs for Utility furniture. To the extent that they explicitly sought to utilise minimise waste in the cutting of wood stock, for example, standardised Utility designs anticipated more recent concerns about 'green design'. However at the same time, the strategy was explicit in its attempt to secure equity of furniture distribution and consumption across the civilian population. As the curator of a 1974 Geffrye Museum exhibition declared: "the Utility scheme, although borne out of necessity, was inspired by ideals of social justice" (Daniels 1974, 3). Crucial to this approach was a distinct spatial strategy in which the state intervened to reorganise - and indeed to regionalise - the whole of the furniture commodity network. 


\subsection{Greening design}

Existing considerations of the Utility furniture scheme primarily have focussed on issues of design aesthetics and the socio-cultural legacy of the scheme in terms of the habits and preferences of a furniture-consuming public (Attfield 1999; Geffrye Museum 1974; Dover 1991). It also has been suggested that Utility was commandeered by a small group of designers led by the entrepreneur and design reformer Gordon Russell in an unsuccessful and misguided attempt to impose new concepts of 'good design' on a reluctant British public (Lucie-Smith, 1979; Dover, 1991; Attfield, 1999). More significant, however, were the resource-saving and manufacturing efficiency measures introduced as part of wartime furniture production, which prefigure debates about 'green design' that emerged much later in the post war period (see also Denney 1999).

The notion that designers should embrace new agendas of social and environmental responsibility, as pioneered by the work of Papanek $(1971,1983,1995)$, has inspired a range of authors to re-evaluate traditional constructs of 'good design' so that they embody principles of sustainability and resource efficiency (for example Lewis et al. 2001; Walker 2006; Thorpe 2007; Chapman and Gant 2007; Whiteley 2006; Massey and Micklethwaite 2009; Chick and Micklethwaite 2011 Walker et al. 2013). The idea of 'green design' advocates new eco-efficient design principles of reuse and recycling to replace traditional linear manufacturing processes and the vast waste streams they generate. The development of cradle to cradle (or $\mathrm{C} 2 \mathrm{C}$ ) regenerative design principles, for example, (Stahel, 1982, McDonough and Braungart 2008) have as their goal the continual circulation of materials with positive social and environmental consequences.

To many environmental design campaigners, the task is to transform the whole premises and ideologies of advanced capitalism in order to create a new resource efficient 'factor four' Natural Capitalism wherein living systems are valued (Hawken 
1993; Welford, 1997; Hawken et al. 1999; Weizsacker, Lovins and Lovins, 1997).

Central to such a transformation are a number of key concepts. The contemporary economy is viewed as inefficient in terms of materials and energy use, demanding a radical increase in resource productivity. The Factor Ten club's 1994 'Carnoules Declaration' seeks a tenfold increase in resource productivity and $90 \%$ decrease in energy and materials intensity. In eliminating waste many analogies and metaphors are drawn from the natural world of ecological systems. Modern manufacturing systems are often wasteful 'industrial metabolisms' with enormous 'ecological footprints' - the ecological capacity underpinning consumption of products (Womack and Jones 1996; see also Gibbs and Deutz 2005; Gibbs, Deutz and Proctor 2005) - with excessive material flows and energy requirements. Biomimicry (see Benyus 1997) involves the redesign of such processes using lessons from biological systems and conceptualizes the ideal economy as analogous to what ecologists call a mature Type Three ecosystem, in which inputs are reduced and waste recycled.

Modern manufacturing, it is suggested, needs to embrace 'cycle' and 'lean thinking' as well as process innovations such as 'closed loop' production systems and 'remanufacturing' which turn wastes into productive use in order to "...overcome the entrenched stupidity of design mentalities" (Hawken et al. 1999, 65). Partly this is a technological process of redesign, deploying new fabrication techniques and new 'pinch technologies' which secure material and energy efficiencies. The elimination of 'Muda' (from the Japanese meaning waste, futility and purposelessness) is crucial. A 'service and flow' customer driven industrial system, with 'extended product responsibility' and 'post-user responsibility' is also important to the elimination of waste. In contrast to traditional 'batch-and-queue' systems, which mass produce large inventories in advance of forecast customer demands, value should flow “... at the pull of the customer ...(and) 
nothing is produced upstream until someone downstream requests it" (Hawken et al. 1999, 127; see also Crocker and Lehmann 2013).

It is interesting to compare the Utility scheme with current thinking about environmental design. A number of key features seem consistent with and serve as early examples of good practice and ecological or 'green' design. First, detailed specifications for a narrow range of furniture designs were developed in order to minimise the overall use of material inputs and to avoid wastage in the cutting of wood stock (details at Board of Trade 1943-49). The Advisory Committee established a panel of designers drawn both from the furniture trade as well as professional design organisations (Hargreaves and Gowing 1952, 515). The 1943 Utility catalogue lists the names of eleven designers who "assisted the Committee in their work," (Mills 2006, 16), and from whom the final set of designs were chosen. The work of designers Edwin Clinch and Herbert Cutler was in the majority, but the designs also included several pieces already in production by specialist firms in High Wycombe, notably the rail backed Windsor chair (Design 1974). The simplicity of Utility designs was seen both to assist firms with the technical demands of manufacturing and to enable them to cope with the pressure of wartime production schedules.

A second element involved the explicit consideration of the ways in which design could enhance longevity:

The design parameters were that the furniture should be strong and serviceable, not in any way temporary... Only hardwoods — oak or mahogany—were to be used and all joints were strongly mortised or pegged. Because plywood was unobtainable, veneered hardwood had to be used for panels... in spite of the shortage of steel, screws were specified in the construction, contributing greatly to the strength of the finished piece (Geffrye Museum 1974, 13). 
In the current era when inexpensive, standardised furnishings (for example, constructed from medium density fibreboard) might be treated as disposable, it is important to underscore that Utility furniture was intended to last, both in terms of materials used and indeed in terms of the overall style and design. The 1946 Working Party Report on furniture was sharply critical, for example, of the pre-war competition-driven practice for:

...very frequent changes in design, changes so frequent as appreciably to interfere with production, and changes which we believe to reflect no underlying change in public taste, but rather to be due to the desire of retailers for something slightly different to assist in pressing sales. (Board of Trade 1946b, 11).

Rapid retailer-led changes in style were considered to be of no benefit to consumers, who might be misled by “...external appearances only” and might find it difficult to assess functionality when confronted with "showy exteriors" (Board of Trade 1946b, 11). Fascinatingly, such a critique of rapid style turnover has parallels with current environmental critiques of 'fast fashion' (Evans 2011; on dynamics in the furniture industry, see Leslie and Reimer 2003, 36). Utility designs also considered the ways in which consumers might be provided with more efficient products: for example, wardrobe storage was maximised by a design which was deep enough to hang clothes sideways, unlike pre-war models (Board of Trade 1946b, 11).

A third aspect of the Utility scheme also is instructive: the overall regulation and certification of Utility designs. The detailed specifications assisted Board of Trade inspectors in monitoring production, to ensure quality and use of correct materials, such as screws versus the inferior substitute, nails: "inspection became impossible unless inspectors knew exactly what they had a right to expect and were able to quote their source of information" (Russell 1968, 198). Although inspectors could only scrutinise a sample of firms, they could "pounce without warning, and look at what was being made 
that day. They rapidly got the drift of those firms that weren't doing as well as they should" (Gordon Russell interviewed in Design 1974, 66). Further, Utility production was guaranteed by a compulsory mark — CC41—on all wartime consumer goods; and once applied the mark could not be defaced or removed (Hargreaves and Gowing 1952, 433). On goods such as clothing, the mark functioned as a label guaranteeing to consumers, producers and retailers a general level of quality and a fair price (De Neuman 1947). Distinctively, Utility furniture was stamped with the CC41 mark in combination with the designation number of the firm which had produced the specific piece of furniture. Although this particular system of traceability may have served more as a means of state regulation rather than as a direct and explicit initiative to increase consumer knowledgeability as we understand it in the current era (on the credibility of environmental certification schemes, see Eden 2009, 2012), Utility furniture labelling did function as a form of accreditation, clearly identifying to the consumer that items had been manufactured to stipulated designs and with specified materials. To the extent

that the mark guaranteed that furniture was built in a resource-efficient manner-both in the sense of materials efficiency as well as assuring localised manufacture-it could even be seen as an early precursor of environmental accreditation (see Massey and Micklethwaite 2009).

\subsection{Sustainability, equity and the commodity network}

The Utility case also reveals shortcomings in debates about green or eco design in as much as they have had a tendency to be preoccupied either with potential improvements in design alone (i.e. pre-production) or with the innovations of a heroic 'sustainable' designer, and underemphasise other important interventions that enable sustainability at a range of nodes across the commodity network. The effectiveness of the Utility furniture scheme rested upon the ability to manage arrangements across a range of sites 
(from design and production to distribution, advertising, retailing and final consumption) in order to deliver environmental sustainability, social equity and resource efficiency. For example, beyond efficiencies in design, there was an important focus on rationalising distribution in order to save scarce petrol resources. Warehousing and marketing of furniture were reoriented; and furniture purchase/consumption was carefully controlled in order to ensure efficiency and equity.

The introduction of the wartime Utility furniture scheme involved a significant spatial reconfiguration of the British furniture industry. The Board of Trade sought to distribute manufacturing capacity more evenly across the whole of Britain, the effect of which was to disperse the traditional geographic concentration of furniture production centred upon London and High Wycombe. Newly designated firms in particular cities and regions were tasked with producing different types of Utility furniture (i.e. chairs, sideboards, wardrobes etc.). This national strategy for the localisation of production had the additional benefit of reducing demands on petrol— not only would designation limit the lengthy road transport of bulky goods for retail distribution but also it reduced the distance furniture would need to travel to the consumer. ${ }^{5}$ Designation also involved directing different firms to manufacture different types of goods: one firm might be designated to supply wardrobes, chests and tallboys, for example; and another to produce dining tables. A secondary impact of this arrangement was to avoid "duplication of effort" among firms within a specific geographical area in order to increase production efficiency at a national scale (Geffrye Museum 1974, 14).

The committee charged with developing standardised Utility designs sought to develop products which could be made across different local labour markets by firms that might not necessarily have had prior expertise in furniture production. The relative simplicity of designs enabled firms to cut wood stock with a minimum of wastage and 
to produce a uniform product with differing available equipment. The standardisation of design processes under the Utility scheme permitted cost control of production as well as facilitating design efficiencies across the national space of the furniture industry (that is, design teams were not needed within individual firms). Such centralised coordination - here explicitly of design — demonstrates the ways in which product innovation might be enabled more widely, such that innovation does not remain piecemeal and localised within a particular set of firms.

Distribution and retailing also were reorganised under Utility. Despite the close monitoring and control of the furniture industry, wartime production levels were insufficiently high to allow retailers or distributors to maintain stock. Retailers held the Board of Trade's Utility furniture catalogue (see Mills 2008), from which items could be ordered. Consumers submitted buying permits to the retailer, who in turn passed the permits to a designated supplier. These arrangements reconfigured existing buyer/supplier relations: it was stipulated that

the designated manufacturers will become general providers for their zone and will no longer give exclusive attention or any specially favourable treatment to the retail firms which have hitherto become their customers. This is an essential part of the zoning scheme designed to save transport. (Board of Trade 1942-43)

Market relations thus no longer governed distribution patterns. Retailers ceased to engage in any form of advertising or marketing: consumer information was provided solely through the Utility furniture catalogue.

Utility furniture buying permits were only valid within a specified geographical area: consumers were instructed that "in order to save carriage of furniture over long distances you may only order utility furniture from a retailer in the area shown on the front of the permit" (Mills 2008, 33). Alongside this reshaping of geographies of consumption, the national state also sought to match consumer demands with scarce 
supplies in an equitable manner. In 1943 buying permits were issued to specific 'priority classes': newlyweds or those proposing to wed, those setting up a new household with young children and bombees (people who had been made homeless or whose properties had been damaged by enemy bombing). There were further extensions later — to refugees for example (Hargreaves and Gowing 1952, 335). Articles of furniture were valued in units roughly corresponding to quantity of materials in them. Permits initially were issued on the basis of need up to a maximum of 60 units, although difficulties with Utility production levels during 1943 and early 1944 required the Board of Trade to reduce the permits issued to households to a value of 30 unitsscarcely sufficient to furnish one room. Permits were valid only for three months and had to be returned if household circumstances changed. Although production levels improved towards the end of the war, the ration was not restored to 60 until 1946 (Hargreaves and Gowing 1952, 336), and the use of a points/permit system continued until June 1948 (Denney 1999, 113). The most significant aspect of the scheme is that whilst consumption obviously was restricted, the state sought to enshrine principles of fairness and equity.

Our foregrounding of equity and sustainability is not intended to be read as an unalloyed celebration of the Utility scheme. Wealthy consumers obviously remained relatively unconstrained by wartime austerity: a fact that was clearly recognised during the Second World War itself. As Zweiniger-Bargielowska $(2000,260)$ has argued,

the notion of common purpose on the home front has to be qualified in view of the widely held opinion that sacrifice affected some more than others and that the rich could still get what they wanted.

Similarly, we also are not suggesting that all aspects of the Utility scheme should be interpreted as environmentally progressive. The restriction of timber imports from their 
pre-war sources increased resource pressure on other locations, leading to significant deforestation both at home and overseas. Tucker, for example, documents that "in thousand year old Crown forests, the Forest of Dean and the New Forest, ancient beech and oak were felled" and that by the end of the war "all merchantable stands were exhausted" $(2004,125)$. Globally, the Utility scheme contributed to increases in the exploitation of tropical hardwoods, with resources from British colonial territories coming under continuing pressure during the post-war British currency crisis, as they were cheaper than 'dollar sources' (Whiteley 1999, 198; see Board of Trade 1949). However, understanding Utility as involving an interlinked set of nodes across the commodity network allows us to foreground the importance of devising strategies to achieve genuinely sustainable outcomes at points of consumption, not just production.

\section{Utility and pragmatic centralism}

Thus far in the paper we have sought to emphasise the role of the wartime national state in developing and managing the Utility furniture scheme. However we also wish to underscore the extent to which the national state as "organising agent" (Bair 2009, 11) operated in a highly pragmatic way, actively soliciting the participation and involvement of other groups and interests as the Utility scheme developed. Our emphasis thus far on the role of the state therefore should not be taken as a contention that state-organised production by definition is environmentally favourable: consider, for example, the environmental failures and calamities which emerged under a command economy in the Soviet Union (Pryde 1991; Nove 1989, 1991). Rather, we take different set of insights from Utility. In particular, we argue that Utility's distinctive pragmatic centralism in practice involved a cross sector response, with multiple participants, organised by the state at a national level but also working through localised routines and procedures. 
Illuminating pragmatic centralism within the Utility scheme avoids a priori dispositions regarding the effectiveness of private markets or regulatory public institutions and prevents “...essentialising social contexts and how people will act in them" (Moore 2010, 259). Our discussion here builds upon and contributes to existing accounts of environmental pragmatism (Benn and Dunphy 2007; Geoforum 2008; Leach et al. 2010; see also Sandbrook et al. 2013). This literature is concerned with the circumstances and interpretations of reality under which the competing ideological orientations will cooperate for good environmental outcomes (Light and Katz 1996). As Coaffee and Headlam $(2008,1587)$ have argued, "pragmatic thinking is vital in solving situationally specific problems." Pragmatism raises questions regarding the circumstances within which actors from a range of sectors will engage in collaborative transboundary management for ecological purposes, which can be taken to be both geographical and sectoral. Pragmatism is an approach which examines how a 'public' that mediates and transcends particularities of interest is brought into being (Barnett and Bridge 2013). It is also an approach that examines the complexities and social embeddedness of environmental debate. As Wood and Smith $(2008,1527)$ have suggested, pragmatism has an important practical and political imperative:

running through many of the pragmatist works is a desire to make the world - bit by bit, unevenly, by accident as well as by design - into a better place; to make positive interventions in a world that is continually in the making.

Such an approach would appear a useful one to take to the study of collaborative arrangements under Utility. We now turn to consider the detailed institutional character of these arrangements, without losing sight of the broader political and historical circumstances under which they came into being. 
According to Dover's (1991) assessment of editorials in the trade magazine Cabinet Maker, furniture manufacturers were initially reluctant to embrace the Utility scheme, a position subsequently moderated for 'patriotic' reasons. The enforced geographical dispersal of the industry and the entry it provided to manufacturers new to furniture production posed a significant problem for the localized and secretive furniture specialists of High Wycombe and East London fearful of losing trade secrets and competitive advantage. The apparent deskilling of furniture production inherent in the Utility scheme - notably, the relinquishing of control over the design of products — was believed to be a threat to both firms and workers. Further, a system of cross inspection and monitoring of Utility production initially deepened suspicion of the state's effort to manage the scheme.

However, the selection of participants to a range of government committees sought to bring diverse voices and participants together in the management of the Utility furniture scheme. The original design specifications were developed by the Advisory Committee on Utility Furniture, established by the Board of Trade in July 1942. The Advisory Committee was chaired by Charles Tennyson, Vice-Chairman of the Council for Art and Industry (a forerunner of the Design Council) and comprised a relatively diverse group of eight initial members (see Table 1). Participants brought local knowledge from across Britain; and membership cut across trade and industry, the civil service, industrial design as well as drawing in experts in housing and urban design. The gender composition of the committee is noteworthy: although one of two women members, "Mrs E Winborn" often was simplistically identified as a "housewife" and seen to represent the 'consumer interest' (Hargreaves and Gowing 1952, 515), as Darling $(2005,51)$ observes, "this was, perhaps, the first time that a woman of the labouring classes was a member of, rather than a witness to, a government committee." 
The Utility Furniture Distribution Committee (UFDC) was set up in November 1942 in order to

follow the furniture through its progress from the manufacturer to the consumer, so that recommendations could be made for dealing with any obstacles which might hinder the machinery of distribution (Board of Trade 1942, 1).

In setting up the UFDC, central government again sought to convene representation from both retailers and manufacturers in the furniture industry; and particularly to integrate members from the powerful High Wycombe trade (see Table 2). An account of the early progress on Utility furniture designations reveals the impact of this influence:

The High Wycombe representatives pressed very strongly for work equivalent to the employment of 300 people, emphasising that Wycombe was the home of the chair trade, that there were numbers of employees not adaptable for other work and that production at Wycombe was specially economical of timber owing to the sorts and cuts which Wycombe is skilled in using (Binney, 1942, 1).

Ultimately, a compromise was established. Kitchen and dining chair production was not decentralised to the same extent as other types of furniture, and High Wycombe remained a specialised chair manufacturing area supplying regions across England, Scotland and Wales. 


\section{Table 1.}

Membership of the Advisory Committee on Utility Furniture.

\begin{tabular}{|c|c|c|}
\hline $\begin{array}{l}\text { Charles } \\
\text { Tennyson } \\
\text { (chair) }\end{array}$ & $\begin{array}{l}\text { Vice-Chairman of the Council for Art and Industry, Chairman of the } \\
\text { Board of Governors of the National Register of Industrial Art Designers, } \\
\text { Secretary of the Dunlop Rubber Company and Late Deputy Director of } \\
\text { the Federation of British Industries }\end{array}$ & Manufacturer \\
\hline $\begin{array}{l}\text { Elizabeth } \\
\text { Denby }\end{array}$ & ARIBA Specialist in the planning and equipment of low-cost housing & $\begin{array}{l}\text { Urban and housing } \\
\text { reformer }\end{array}$ \\
\hline John Gloag & ARIBA Consultant on industrial design & Designer \\
\hline $\begin{array}{l}\text { Charles } \\
\text { Jenkinson }\end{array}$ & $\begin{array}{l}\text { Vicar of St John and St Barnabas, Leeds. Former chair of Leeds } \\
\text { Corporation Housing Committee }\end{array}$ & Consumer \\
\hline W Johnstone & $\begin{array}{l}\text { Furniture manufacturer and member of the Executive of the Furniture } \\
\text { Committee of the Scottish Committee of the Council for Art and Industry }\end{array}$ & Manufacturer \\
\hline $\begin{array}{l}\text { Herman } \\
\text { Lebus }\end{array}$ & Senior partner in the firm of Harris Lebus, furniture manufacturers & Manufacturer \\
\hline $\begin{array}{l}\text { Gordon } \\
\text { Russell }\end{array}$ & Furniture designer and director of Gordon Russell Ltd., Worcestershire & Designer \\
\hline V Welsford & $\begin{array}{l}\text { Manager of the Furniture Factories of the Cooperative Wholesale } \\
\text { Society (CWS) }\end{array}$ & Manufacturer/retailer \\
\hline Elsie Winborn & Member of the Tenants' Committee of the Kensal House Estate & Consumer \\
\hline
\end{tabular}

Source: adapted from Geffrye Museum $(1974,12)$.

\section{Table 2.}

Membership of the Utility Furniture Distribution Committee.

\begin{tabular}{|l|l|l|}
\hline Herman Lebus (chair) & Senior partner in Harris Lebus & Manufacturer \\
\hline D Barber & Retail Distributors Association & Retailer \\
\hline J Paynton & Drapers Chamber of Trade & Textile manufacturer \\
\hline C Grieg & Hire Purchase Traders Association & Retailer \\
\hline G Rogers & Relaxawell Works, Soho Street, Liverpool & Manufacturer \\
\hline AE Barnes & High Wycombe and District Furniture Manufacturers Federation & Manufacturer \\
\hline FA Greaves & Furniture Manufacturers Association, London Chamber of Commerce & Manufacturer \\
\hline A Jaines & High Wycombe Furniture Association & Manufacturer \\
\hline A Maclnnes (Miss) & Board of Trade & State \\
\hline JR Lander & & \\
\hline
\end{tabular}


Trade union representatives also were carefully drawn in to arrangements for Utility furniture production. Head of the Board of Trade Hugh Dalton added A. G. Tompkins, the secretary of the National Union of Furniture Trades, to the Utility furniture Advisory Committee in January 1943; and Tompkins' knowledge and experience was seen to be "clearly useful in promoting cohesion between the Board of Trade, the manufacturers and the workers" (Geffrye Museum 1974, 29; see also Reid 1986). By the end of the war unions were being explicitly consulted on additional designation of furniture manufacturers (see Walker 1945). Finally, key figures in two of the very largest British furniture manufacturers had central roles in the organisation of the Utility furniture scheme: Lucian Ercolani of Ercol was member of the Timber Supplies Committee of the Furniture Trade (a branch of the Board of Trade's Timber Control) and Herman Lebus chaired the Utility Furniture Distribution Committee.

The types of pragmatic arrangements we have outlined, devised in response to deep wartime shortages, enabled the national state to achieve results very quickly. The Utility scheme was designed and delivered in a matter of months, yet it also was to be flexible and adaptive. Production levels were consistently monitored in different parts of the country and detailed records kept to ensure the 'balancing' of production and demand. When production lags were identified, the Board of Trade sought to designate additional manufacturing firms and also to manage demand through reductions in the issue of consumers' buying permits. As Hargreaves and Gowing (1952, 321-322) concluded,

in spite of all its teething troubles the utility furniture scheme was one of the notable war-time successes on the home front. It brought together many strands of policy — the production of a minimum of domestic furniture of reasonable quality, production with the minimum of raw material, price control, rationing, and release of labour and factory space... and although the allowance of furniture was so 
austere, the scheme did help to alleviate the personal problems of thousands of families by providing pleasant furniture at reasonable prices.

The case of Utility offers a useful lens through which to assess possibilities for network formation as a means of enhancing environmental outcomes. According to Kelly, new organisational forms, such as 'distributive intelligence systems' (1995, cited Hawken et al, 1999, 67) are necessary to challenge traditional centralised and hierarchical corporate control structures. In contrast to attempts to enforce commands from a single source down through layers of authority,

distributed intelligence [...] uses many decentralised decision-makers of comparable power, interpreting events under shared roles, interacting with and learning from each other, and controlling their collective behaviour through the interaction of their diverse local decisions, much like an ecosystem works (Hawken et al. 1999, 67).

The organisational arrangements for Utility are, in contrast, better characterised as pragmatic centralism. Whilst plans were predominantly established at a national level, the Board of Trade nevertheless operated strategically to obtain support and advice from a range of variously positioned actors across different local areas. Although decisionmaking was not spatially devolved, local demand and production were monitored and adaptions made. Ultimately, such pragmatic centralism was crucial both to the evenness of outcomes across the national space-economy and to the speed with which the Utility scheme was implemented.

\section{Conclusions}

This paper has utilised archival evidence of the British wartime Utility furniture scheme to reflect upon lessons for contemporary debates surrounding sustainable and equitable environmental practice. Analysis of a moment of wartime crisis offers the 
possibility of countering present day expectations about the efficiency of private market relationships in delivering sustainable futures. The Utility scheme was driven by a need to eliminate waste; to manage the use and consumption of scarce natural resources during a period of national emergency; and to combat the failings and distortions of consumer goods markets under crisis conditions. During the Second World War the British state became a key organising agent of the furniture commodity network, estimating levels of demand, designating manufacturers, allocating levels and sites of production, specifying product designs, and intervening in final distribution and consumption. Distinctively, these interventions were made on the basis of social need and welfare, rather than market profitability. Moreover, local outcomes were achieved by national coordination and direction.

Foregrounding the national state as an organising agent in our discussion of Utility allows us to re-establish the conceptual importance of understanding state action within accounts of commodity networks more broadly. As Smith has argued,

this is not a call to return to the nation-state-centric analyses of economic development prevalent in so much social science scholarship on development, but it is to argue for the consideration of the constitutive role of state action at various scales in the establishment and restructuring of production networks $(2014,2)$.

Whilst Smith's (2014; see also Smith et al., 2002) intent is an illumination of macroregional contexts, his suggestions for readings of the state that are attentive to the "configuration of social forces underpinning state support for particular policy directions" $(2014,10)$ are instructive for our analysis of Utility within a national spaceeconomy. The necessity of direct intervention - to the extent of reconfiguring the furniture commodity network itself - may have been prompted by an extreme case (i.e. war) but the emergent resolution of crisis and scarcity was sought via a pragmatic coordination of interests, which we have termed 'pragmatic centralism.' A 
consideration of the Utility furniture scheme draws important attention to the kinds of processes and negotiations involved in restructuring commodity networks for a new set of purposes and social values, the spatial logics this involves and the sectoral and geographical legacies that may be left behind. 


\section{References}

Addison, P. 1975. The road to 1945: British politics and the Second World War. London, Jonathan Cape.

Attfield, J., ed., 1999. Utility reassessed: the role of ethics in the practice of design, Manchester, Manchester University Press.

Bair, J., ed., 2009. Frontiers of commodity chain research Stanford, CA, Stanford University Press.

Barnett, C. and Bridge, G., 2013. Geographies of radical democracy: agonistic pragmatism and the formation of affected interests, Annals of the Association of American Geographers 103: 1022-1040.

Benn, S. and Dunphy D., eds., 2007. Corporate governance and sustainability: challenges for theory and practice. London, Routledge.

Benyus, J., 1997. Biomimicry: inspired by nature. New York, Morrow.

Binney, H.A.R., 1942. Memorandum: Progress on designation of firms to make utility furniture, 10 November 1942, Board of Trade, Correspondence re designations, BT 64/1816 The National Archives, Kew.

Board of Trade 1942. Minutes of the first meeting of the Utility furniture distribution committee $2^{\text {nd }}$ November 1942 BT 64/1749.

Board of Trade 1942-1943. Correspondence re designations BT 64/1816 The National Archives, Kew.

Board of Trade 1942-1944a. Advisory committee on Utility furniture BT 64/1835 The National Archives, Kew.

Board of Trade 1942-1944b. Utility Furniture Distribution Committee BT 64/1749 The National Archives, Kew.

Board of Trade 1943-49. Utility furniture scheme: files BT 183 The National Archives, Kew.

Board of Trade. 1946a. Utility Furniture. Correspondence with Advisory Committee BT 64/1897 The National Archives, Kew.

Board of Trade 1946b. Working party reports: furniture London, HMSO

Board of Trade 1949. Report of the Committee Appointed to Consider the United Kingdom's Probable Requirements and Supplies of Timber and Plywood 1949 to 1953 London, HMSO.

Buttel F.H., 2000. Ecological modernisation as social theory, Geoforum 31 57-65. 
Caniëls, M.C.J and Romijn, H.A., 2008 Strategic niche management: towards a policy tool for sustainable development, Technology Analysis \& Strategic Management, 20: 245-266

Chapman, J., and Gant, N., 2007. Designers, visionaries and other stories: a collection of sustainable design essays. London, Earthscan.

Chick, A and Micklethwaite, P., 2011. Design for sustainable change: how design and designers can drive the sustainability agenda. Lausanne, AVA Academia.

Coaffee, J. and Headlam, N., 2008. Pragmatic localism uncovered: experiences from English urban policy reform, Geoforum 39: 1585-1599.

Crocker, R., and Lehmann, S., (eds.) 2013. Motivating change: sustainable design and behaviour in the built environment, London, Routledge/Earthscan.

Daniels, J., 1974. Foreword. In Geffrye Museum. Utility furniture and fashion 19411951 London, Geffrye Museum/Inner London Education Authority, p. 3.

Darling, E., 2005. A citizen as well as a housewife: new spaces of femininity in 1930s London. In H. Heynen \& G. Baydar, eds. Negotiating domesticity: spatial productions of gender London: Routledge, pp. 49-64.

de Marchi, V., di Maria E., Ponte, S., 2013. The greening of global value chains: insights from the furniture industry, Competition and Change 17: 299-318.

de Marchi, V.D., di Maria, E. and Micelli, S., 2013. Environmental strategies, upgrading and competitive advantage in global value chains. Business Strategy and the Environment, 22: 62-72.

Daniels, J., 1974. Foreword In Utility furniture and fashion 1941-1951 London, Geffrye Museum/Inner London Education Authority, p. 3.

de Neuman, A.N., 1947. L'economia dei prodotti inglesi tipo "Utility" Giornale degli Economisti e Annali di Economia, 6: 355-371.

Denney, M., 1999. Utility furniture and the myth of Utility 1943-48. In J. Attfield, ed., Utility reassessed: the role of ethics in the practice of design. Manchester, Manchester University Press, pp. 110-124.

Design 1974. Gordon Russell interviewed in Utility: how a wartime government hired its own designers to give the furniture industry a compulsory range of consumer products, Design 309: 63-71.

Dover, H., 1991. Home front furniture: British Utility design, 1941 to 1951. Aldershot: Scolar Press. 
Eden, S., 2009. The work of environmental governance networks: traceability, credibility and certification by the Forest Stewardship Council, Geoforum 40: 383-394

Eden, S., 2012. Eco-labels. In G. Ritzer, ed., The Wiley-Blackwell encyclopaedia of globalization Oxford, Blackwell.

Evans, D., 2011. Thrifty, green or frugal: Reflections on sustainable consumption in a changing economic climate, Geoforum 42: 550-557

First report from the Select Committee of the House of Lords on the Sweating System, PP 1888 (361).

Ford P., 1951. The allocation of timber. In D.N. Chester, ed., Lessons of the British war economy. Cambridge, Cambridge University Press, pp. 144-153.

Frost, O. H., 1942. Price control of new furniture. Memorandum from O.H. Frost, Vice-Chairman of the Central Price Regulation Committee, 30 June 1942. Board of Trade, Advisory Committee on Utility Furniture BT 64/1835 The National Archives, Kew.

Geels, F. W. 2013. The impact of the financial-economic crisis on sustainability transitions: Financial investment, governance and public discourse. Environmental Innovation and Societal Transitions 6: 67-95.

Geffrye Museum 1974. Utility furniture and fashion 1941-1951 London, Geffrye Museum/Inner London Education Authority

Geoforum 2008. Themed issue: pragmatism and geography, Geoforum 39: 4

Gereffi, G., Humphrey, J., Kaplinsky, R., and Sturgeon, T.J., 2001. Introduction: Globalisation, Value Chains and Development, IDS Bulletin 32: 1-8.

Gibbs, D., 2000. Ecological modernisation, regional economic development and regional development agencies, Geoforum 31: 9-19.

Gibbs D., 2006. Prospects for an environmental economic geography: linking ecological modernization and regulationist approaches, Economic Geography 82 193-215.

Gibbs, D., and Deutz, P. 2005. Implementing industrial ecology? Planning for ecoindustrial parks in the USA. Geoforum, 36: 452-464.

Gibbs, D., Deutz, P., and Proctor, A. (2005). Industrial ecology and eco-industrial development: A potential paradigm for local and regional development?. Regional Studies, 39: 171-183. 
Goger A., 2013. The making of a 'business case' for environmental upgrading: Sri Lanka's eco-factories, Geoforum 47: 73-83

Hall, P.G., 1962. The industries of London since 1861 London, Hutchinson

Handfield, R.B., Walton S.V., Seegers L.K., Melnyk, S.A., 1997. 'Green' value chain practices in the furniture industry, Journal of Operations Management 15 293315.

Hargreaves, E.L. and Gowing, M.M., 1952. Civil industry and trade London, Longmans and HMSO.

Hawken, P., 1993. The ecology of commerce: a declaration of sustainability New York, Harper Business.

Hawken P., Lovins A., Lovins L.H., 1999. Natural capitalism: creating the next industrial revolution. Boston, Little Brown and Company.

Høgelvold, N.M., 2011. A corporate effort towards a sustainable business model: a case study from the Norwegian furniture industry, European Business Review 23: 392-400.

Hough, P., 2011. Disarticulations and commodity chains: cattle, coca, and capital accumulation along Colombia's agricultural frontier, Environment and Planning A 2011 43: 1016-1034.

House, F.H., 1965. Timber at war: an account of the organisation and activities of the Timber Control 1939-1945 London, Benn

Hughes, A., and Reimer, S. (eds.), 2004. Geographies of commodity chains. London, Routledge.

Kaplinsky, R.; Readman, J. and Memedovic, O., 2009. Upgrading strategies in global furniture value chains. United Nations Industrial Development Organization (UNIDO). Available at:

http://www.unido.org/fileadmin/user_media/Publications/Pub_free/Upgrading_s trategies in global furniture value chains.pdf Accessed 3/11/2010.

Khattak, A., Stringer, C., Benson-Rea, M., \& Haworth, N., 2015. Environmental upgrading of apparel firms in global value chains: Evidence from Sri Lanka. Competition and Change 19: 317-335.

Kirkham, P., Mace, R. and Porter, J., 1987. Furnishing the world: the East London furniture trade 1830-1980. London, Journeyman. 
Kemp, R., Schot, J and Hoogma, R., 1998 Regime shifts to sustainability through processes of niche formation: The approach of strategic niche management, Technology Analysis \& Strategic Management, 10: 175-198

Leach M., Scoones I., Stirling A., 2010. Dynamic sustainabilities: technology, environment, social justice. London, Earthscan

Lewis, H., Gertsakis, J., Grant, T., Morelli, N., and Sweatman, A., 2001. Design + environment: a global guide to designing greener goods. Sheffield, Greenleaf.

Leslie, D. and Reimer, S., 2003. Fashioning furniture: restructuring the furniture commodity chain, Area 35: 427-437.

Leslie, D. and Reimer, S., 2006. Situating design in the Canadian household furniture industry, The Canadian Geographer 50: 319-341.

Light, A. and Katz, E., eds., 1996. Environmental pragmatism, London, Routledge

Lovell, H., 2007. The governance of innovation in socio-technical systems: the difficulties of strategic niche management in practice, Science and Public Policy 34: $35-44$

Lucie-Smith, E. 1979. Furniture: a concise history London, Thames \& Hudson.

MacGregor, J.J., 1953. The source and nature of statistical information in special fields of statistics: timber statistics, Journal of the Royal Statistical Society 116: 298322.

Maskell, P., 1998. Localised low-tech learning in the furniture industry. In M. Lorenzen, ed. Specialisation and localised learning: Six studies on the European furniture industry. Copenhagen, Copenhagen Business School Press, pp. 33-58.

Massey, A. and Micklethwaite, P., 2009. Unsustainability: towards a new design history with reference to British utility. Design Philosophy Papers, 7: 123-135.

McDonough, W. and Braungart, M., 2008. Cradle to cradle: remaking the way we make things. London, Jonathan Cape.

McIlhenney, K. and Hayter, R., 2013. Sustaining jobs and environment? the valueadded wood industry in Metro Vancouver, British Columbia, Local Environment published online 25 Nov 2013.

Mills, J., 2008. Utility Furniture Sevenoaks, Sabrestorm.

Moore S., ed., 2010. Pragmatic sustainability: theoretical and practical tools London, Routledge. 
Nove A., 1989. Socialism, capitalism and the Soviet experience, Social Philosophy and Policy 6: 235-251.

Nove, A., 1992 [1969]. An economic history of the USSR, 1917-1991. Third Edition. London, Penguin.

ONeill K.J .and Gibbs D.C., 2013. Towards a sustainable economy? Socio-technical transitions in the green building sector, Local Environment Published online: 22 Jul 2013

Papanek, V., 1971. Design for the real world: human ecology and social change. New York, Pantheon Books.

Papanek, V., 1983. Design for human scale. New York, Van Nostrand Reinhold.

Papanek, V., 1995. The green imperative: Natural Design for the Real World, New York, Thames and Hudson.

Pett C. and Cayli E., 2008. 'Utility furniture and 21st Century design thinking', Presentation to the 20th Century Furniture Research Group, High Wycombe, Friday 21st November. http://www.plidesign.co.uk/wp-content/uploads/Utilitylecture-21 November 2008.pdf, accessed 14 September 2012.

Pevsner, N., 1937. An enquiry into industrial art in England. Cambridge, Cambridge University Press.

Pryde, P.R., 1991. Environmental management in the Soviet Union Cambridge, Cambridge University Press.

Rees, J., 1992 Markets - the panacea for environmental regulation? Geoforum 23: 383-394.

Reid, H., 1986. The furniture makers: a history of trade unionism in the furniture trade 1865-1972. Oxford, Malthouse Press.

Reimer, S., \& Leslie, D., 2008. Design, national imaginaries, and the home furnishings commodity chain. Growth and Change, 39: 144-171.

Reimer, S., \& Pinch, P., 2013. Geographies of the British government's wartime Utility furniture scheme, 1940-1945. Journal of Historical Geography 39: 144-171.

Russell G., 1968. Designer's trade: an autobiography. London, Allen and Unwin.

Sandbrook, C.G., Fisher J.A. and Vira, B., 2013 What do conservationists think about markets? Geoforum 50 232-240.

Schot, J.W and Geels, F.W., 2008 Strategic niche management and sustainable innovation journeys: Theory, findings, research agenda and policy, Technology Analysis \& Strategic Management 20: 537-554. 
Scott, A.J., 1996. Economic decline and regeneration in a regional manufacturing complex: southern California's household furniture industry, Entrepreneurship and Regional Development 8: 75-98.

Scott A.J., 2006. The changing global geography of low-technology, labour-intensive industry: clothing, footwear, and furniture, World Development 34: 1517-1536.

Scott P. and Walsh, P., 2004. Patterns and determinants of manufacturing plant location in interwar London, Economic History Review 57: 109-141.

Smith, A., Rainnie, A., Dunford, M., Hardy, J., Hudson, R., and Sadler, D., 2002. Networks of value, commodities and regions: reworking divisions of labour in macro-regional economies, Progress in Human Geography 26: 41-63.

Smith, A., 2014. The state, institutional frameworks and the dynamics of capital in global production networks Progress in Human Geography, published online 7 February 2014.

Stahel, W.R., 1982. The product-life factor. Geneva, The Product-Life Institute.

Thorpe, A., 2007. The designer's atlas of sustainability: charting the conceptual landscape through economy, ecology and culture. Washington, DC, The Island Press.

Tucker R.P., 2004. The World Wars and the globalisation of timber cutting. In R.P. Tucker and E Russell, eds., Natural enemy, natural ally: toward an environmental history of warfare. Portland, Oregon State University Press, pp. 110-139.

Vaizey, J., 1974. 'Introduction' in Utility Furniture and Fashion 1941-51, London, Geffrye Museum/Inner London Education Authority, County Hall.

Walker, C.H., 1945. Letter on trade unions and designation, to Elliots of Newbury, $30^{\text {th }}$ January 1945 Board of Trade, Utility Furniture. General Policy BT 64/2052, The National Archives, Kew.

Walker, S., 2003. Sustainable by design: explorations in theory and practice London, Earthscan.

Walker S., Giard, J., Walker, H., eds., 2013. Handbook of design for sustainability London, Bloomsbury.

Weizsacker, E. von, Lovins, A.B., Lovins L.H., 1997. Factor four: doubling wealth, halving resource use. London, Earthscan.

Welford, R., ed., 1997. Hijacking environmentalism: corporate responses to sustainable development, London, Earthscan 
Whiteley, N., 1999. Utility, design principles and the ethical tradition' in J. Attfield, ed., Utility reassessed: The role of ethics in the practice of design. Manchester, Manchester University Press, pp. 190-202.

Whiteley N., 2006 [1993]. Design for society London, Reaktion. Reprinted 2006.

Womack, J.P. and Jones D.T., 1996. Lean thinking: banish waste and create wealth in your corporation. New York, Simon and Schuster.

Wood N. and Smith S., 2008. Pragmatism and geography, Geoforum 29 1527-1529.

Zweiniger-Bargielowska, I., 2000. Austerity in Britain: rationing, controls and consumption 1939-1955 . Oxford, Oxford University Press. 
${ }^{1}$ We are grateful to one of the paper's referees for helping us to clarify our use of the term pragmatic centralism.

${ }^{2}$ Empirically this study is based on analysis of a range of archival sources: the extensive records of the Board of Trade held at the National Archives, Kew; Mass Observation archives deposited at the University of Sussex, and Census of Production data on the British furniture industry. Unless specified otherwise, the general narrative detail of the Utility furniture scheme is derived from these sources.

${ }^{3}$ For critical geographical reviews of ecological modernisation, see Gibbs 2000, Buttel 2000 and Gibbs 2006. A much earlier questioning of the role of the market in delivering sustainable outcomes is provided in Rees (1992).

${ }^{4}$ Data derived from the 1935 Census of Production, published 1944. The furniture industry was not included in surveys conducted under the Import Duties Act (1937/38), and processing of all late 1930s data was delayed by the onset of war. Publication of the 1935 Census of Production was postponed because of the destruction of the typeset manuscript, and the 1944 publication had to rely on the photographic reproduction of galley proofs.

${ }^{5}$ There was extensive debate at successive meetings of the Utility Furniture Distribution Committee about the relative merits and efficiencies of road versus rail transport (Board of Trade 1942 and passim BT 64/1749). Rail transport was at the time considerably more fuelefficient relative to a traditional furniture van, given contemporary vehicle technologies, but furniture manufacturers - particularly longer-established High Wycombe firms — were strongly opposed to moving furniture by rail because they believed it to cause product damage. However the Ministry of War Transport ultimately insisted that furniture should not be transported for more than sixty miles by road — and indicated that they would refuse petrol allocations for longer journeys. 